\title{
Response to Aurelie A. Hagstrom
}

\section{Marc Muskavitch}

First, I want to think Aurelie for her paper and her presentation, and I'd like to do three things. I want to summarize some of the key points, as I see them, from her presentation and from my perspective as a scientist. Then, I'd like to address three particular statements that Aurelie makes. Finally, I'd like to frame some questions that we might consider.

Aurelie has presented us with a rich exploration of the origins and evolution of hospitality. In her paper, she talks about its etymology and then discusses its conceptualization and realization through the Old and New Testaments, and down to the present day. She invites us to think about God's hospitality: the invitation to love God and to be joined with God in covenant, and the invitation to be loved by God and to be joined with God through incarnation and rebirth. She lays out concepts and incarnations of host and guest through history, and she raises a number of issues that encompass Catholic institutional identity and practice, in relation to how we "set the table" at our institutions.

Aurelie quotes John Haughey: "A Catholic university should house plural world views

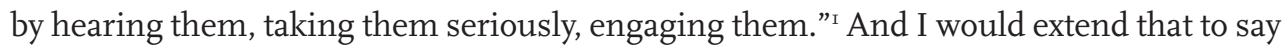
that, in authentic dialogue, the members of our universities should be open to genuine listening, learning, and change, to discovery, and even to revelation.

My personal perspective on this is as a scientist. I'm most centrally a geneticist. And I regard myself as an amateur Ignatian, because I've only been among Jesuits for twelve years. And, after twelve years among Jesuits, how could one be anything but only an amateur? I host a number of students in my work. I teach genetics, and I host many pre-medical students in my classes and in my office. And I'm willing to share all sorts

1. John C. Haughey, S.J., Where Is Knowing Going? The Horizons of the Knowing Subject (Washington, D.C.: Georgetown University Press, 2009).

Marc Muskavitch is a professor of biology at Boston College. He is a widely published geneticist and co-inventor with more than a dozen patents. His research interests include malaria and vector biology, vector mosquito genomics and genetics, and malaria parasite proteasome function. His work has appeared in numerous scientific journals, including Acta Tropica, Genetics, Cell, Nature, and Science. 
of advice with them. And one piece of advice I share is that-because often they're wrestling about medical school-M.D.'s are trained to believe they must always be right, and Ph.D.'s, particularly in the sciences, are trained to believe that they will often be wrong, but that this is all right.

The distinction is based on the framework that Karl Popper stated most clearly, the hypothetico-deductive approach to understanding, knowledge, and insight. ${ }^{2}$ Science is really based, in this ideal, on the construction and then the refutation and then the reconstruction-one hopes in an improved way-of a hypothesis that illuminates some facet of the material world. Scientists, in my view, should be open to and hospitable to error-error in the service of the discovery of a more perfect insight or a more perfect truth regarding a facet of the material world.

At this Roundtable, I would extend Popper's insight and propose that academic scholars are actually called to be open and to be hospitable to wrestling with uncertainty and to exploring error in seeking encounters with truth, both with those who are like-minded and those who are other-minded. They should be open to discovery and to revelation, both in the material realm and the abstract realm. That is my premise.

Let me, then, address three particular points that Aurelie makes. At one point, she states that hospitality, as a framework and a practice, has the potential to integrate Catholic identity into the various dimensions of campus life. How do we achieve that integration of framework and practice? Within the context of Jesuit Catholic education at Boston College, we invite our students, we ask our students-we actually implore our students - to be attentive and reflective and loving. We do that in the hope that they're going to choose to live thoughtful and meaningful lives. I would suggest, though, that we should ask the same of ourselves. Faculty, staff, and administrators can also strive to be attentive and reflective and loving, in our work and in our relationships with our students and even-dare I say-with one another.

Tom Plante indicated that at Santa Clara, many students move from college into the tech sector. He tells students that they're really focused on "R and D," which is not research and development, but rather reflection and discernment. Given this Ignatian emphasis on reflection and discernment, we can also think about a framework and a practice in which we invite our students and our colleagues to engage in a recurrent process of reflection, discernment, decision, and action, as our students and colleagues travel along the paths of their lives within the academy and beyond. This invitation to thoughtful living can extend to and encompass both the material and the abstract realms.

The second point that Aurelie raises is that we set the table at our institutions, and we set that table for our students, for our colleagues, for our guests, and for the other. I would propose that at that table, what we are striving to do is to offer sustenance. But we are academics, after all, so what is that sustenance? It's knowledge, it's insight, and,

2. Karl R. Popper, Objective Knowledge: An Evolutionary Approach (Clarendon Press, 1979). if we dare, it's a way of proceeding. A way of proceeding that can sustain our students on their journeys through life.

Now, because we have diverse students, we can consider offering different students different food. They are distinct individuals. And their journeys have been and will be different in deeply personal ways. James Martin frames the idea that there are six paths to God or, we might say, to transcendent insight: the paths of belief, independence, disbelief, return, exploration, and confusion. ${ }^{3}$ Now, many of the members of our communities travel along the path of belief, the path of Catholic belief, even though each person travels a personal path. But, in addition, as Aurelie noted, there are ever more members of our communities who espouse a variety of beliefs, or think they espouse no belief at all. How do we respond to encounters with them?

Again, I'd appeal to Haughey. He states that the notion of catholicity must be freed and allowed to be in dialogue with the world's peoples, with their many needs, their plural belief systems, and their visions of the good and true. Let me suggest that in the spirit of hospitality, we can choose to invite diverse peoples into our communities, with diverse needs, beliefs, and visions. We can choose to actively encourage the students who travel along those different paths that, in fact, these different paths are expected and accepted, and that these students are welcomed within our academic communities, and specifically within our Catholic institutions.

The third point that I want to address is that Aurelie notes that the word that the New Testament uses for hospitality is philoxenia, which refers not to literal love of strangers, but to the delight in the host-guest relationship. Bernard Lonergan summarizes the practice of being an authentic human as being based on what he calls transcendental precepts: being attentive, intelligent, reasonable, responsible, and loving. ${ }^{4}$

Now I'm going to talk about love, which we don't usually talk about. Let me suggest that the Catholic ethos of our institutions calls us, and actually dares us, to love one another as God has loved us. We ought to regard our students as beloved guests and strive to embody this love, motivated by the spirit of hospitality. As members of the academy, and as scholars and teachers, we're actually called to love many things as well: to love inquiry and truth and dialogue, to love discovery, teaching, and learning, to enable change within others, to expect change within ourselves, and to work for beneficial change within our institutions. As members of the academy and as hosts, motivated by our love for them, I think we're called to provide our students with sustenance at the table that we continue to set for their journey while they are within the academy, and also for their extended journey beyond the academy.

Let me finish by framing some questions we might consider.

I. As members of the academy, and members of institutions that are grounded in the Catholic ethos, how in the past, how in the present, and how

3. James Martin, S.J., The Jesuit Guide to (Almost) Everything: A Spirituality for Real Life (San Francisco: HarperOne, 2012)

4. Bernard J. F. Lonergan, S.J., Method in Theology (Herder and Herder, 1972). 
might we better in the future integrate the value and practice of hospitality into the lives of our Catholic institutions?

2. Aurelie states that hospitality can be a framework and a practice. We might ask ourselves: What is that framework, and what is our practice?

3. She reminds us that as hosts, we set the table. So we might ask, when we consider how we set the table within our Catholic institutions: How has it been set in the past, and how should it be set in the future?

4. She notes that Ex Corde Ecclesiae challenged the Catholic academy to consider the identity and mission of our colleges and universities. We might ask: Are the Catholic identities of our institutions welcoming and inclusive? Are they grounded-are they truly grounded-in hospitality? And to the extent they're not, should they become more so?

5. Finally, Aurelie reminds us of the Latin roots and the words hospes for host and hostis for enemy. So we might ask: How effective are we in incarnating the spirit of hospitality within our Catholic institutions? Is that hospitality evident to those who are on the outside looking in? And how can our Catholic institutions, our academic communities, live and work more effectively—and be perceived more clearly—as hospes? 